diary creamers," confections, and cooking oils. Yet coconut oil is $85 \%$ saturated, has a particularly low iodine-value, and contains large amounts of palmitic and lauric acids. ${ }^{23}$ Palmitic and myristic acids are regarded as particularly potent atherogenic agents, ${ }^{24}$ and the level of myristic acid is raised in the serum of patients with ischaemic heart disease. ${ }^{25}$ Its composition makes coconut oil an even less desirable component of the diet than dairy fats, beef-fat, and the like. If people are consuming more vegetable oils, they should insist on eating the right sorts-such as corn oil, soya-bean oil, or preferably sunflower-seed oil-and not one that is more saturated than "animal fat." Rapeseed oil, owing to its high content of erucic acid, is known to be cardiotoxic in animals, ${ }^{26}$ so that it would seem to be a most undesirable vegetable oil. But how are the public to know? They have a right to be informed about "vegetable oils." Manufacturers should declare the source and major composition of all fats used in foodstuffs. ${ }^{21} 22 \mathrm{~A}$ deplorable commercial secrecy envelops the topic of edible fats.

The public are also ignorant about the extent and effects of hydrogenating PUFA to make them more solid. This is reputed to cause trans-unsaturated fatty acids to be formed. The cholesterol esters of these fatty acids are known to be highly fibrogenic. ${ }^{27}$ Again the facts should be divulged. It is disturbing that we consume commercially processed foods without considering what they contain, how they are made, or what harm they may do.

1 Pinckney, E. R., American Heart Fournal, 1973, 85, 723.

2 Pinckney, E. R., American Heart 7nurna

3 Pearce, M. L., and Davton, S., I.ancet, 1971, 1. 464

4 Pearce, M. L., and Davton, S., L.ancet, 1971, 1. 464 . lainen, E., Lancet, 1972, 2, 835 .

5 Fleischer, S., and Rouser, G., Fournal of the American Oil Chemists' Society, 1965, 42, 588

O'Brien, J. S., Science, 1965, 147, 1099.

7 Granados, H., and Dam, H., Acta Pathologica Microbiologica Scandinavica, 1950, 27, 591 .

8 Friede, R. L., Acta Neuronathologica, 1962, 2, 113.

9 Hartroft, W. S., Fournal of Gerontology, 1953, 8, 158

10 Aoyama, S., and Iwakami, M., Fananese Heart fournal, 1965, 6, 128.

11 Tappel, A. L., Annals of the New York Academy of Sciences, 1972, 203, 12.

12 Jones, D., Gresham, G. A., Lloyd, H. G., and Howard, A. N., Nature, 1965, 207, 205.

Allison, R. S., Proceedings of the Royal Society of Medicine, 1963, 56, 71. Imai, T., Kubo, T., and Watanabe, H., Fournal of the National Cancer Institute, 1971, 47, 179

15 Dunham, L. I., and Bailar, J. C., fournal of the National Cancer Institute, $1968,41,155$

16 Fortuine, R., Cancer, 1969, 23, 468.

International Union Against Cancer, Cancer Incidence in Five Continents, Vol. 2, ed. R. Doll, C. Muir, and J. Waterhouse. Berlin, Springer, 1970. 18 Clayson, D. B., Chemical Carcinogenesis. London, Churchill, 1962.

19 Jager, F. C., Annals of the New York Academy of Sciences, 1972, 203, 199. Symposium: Biological Significance of Autoxidized and Polymerized Oils, Lipids, 1973, 8, 329 .

21 Atherosclerosis Study Group, Circulation, 1970, 42, A-55.

22 Fredrickson, D. S., British Medical fournal, 1971, 2, 187.

23 Thorpe, J. F., and Whiteley, M. A., Thorpe's Dictionary of Applied Chemistry, Vol. 3, p. 241. London, Longmans, 1939.

24 Kritcehvsky, D., and Tepper, S. A., Progress in Biochemical Pharmacology 1968, 4, 474 Symposium: Recent Advances in Atherosclerosis, cology, 1968, 4, 474. Symposium: Recent Advances in Atherosel. Basel.

25 Colehour, J. K., and Leonard, R. H., Clinica Chimica Acta, 1964, 9, 413.

25 Colehour, J. K., and Leonard, R. H., Clinica Chimica

27 Abdellatif, A. M. M., Nutrition Reviews, 1972, 30, 2 . ology and Bacteriology, 1967, 94, 63.

\section{Diagnosis of Childhood Spinal Muscular Atrophy}

A severe form of spinal muscular atrophy developing at or soon after birth and leading to hypotonia and progressive muscular weakness is known as Werdnig-Hoffmann disease. A more benign form is now recognized as being relatively common in childhood and adolescence. E. Kugelberg and L.
Welander ${ }^{1}$ were among the first to define this syndrome, which is sometimes called "pseudomyopathic spinal muscular atrophy." Controversy persists on whether it represents a distinct clinical and genetic entity or the benign end of a range of disease with severe Werdnig-Hoffmann disease at the other end. Severe and relatively benign cases may sometimes be seen in the same sibship, ${ }^{2-4}$ but there is growing evidence $^{5}$ to indicate that despite such atypical families spinal muscular atrophy of childhood contains at least three subvarieties which are clinically and genetically distinct. The first of these, it is suggested, is classical and severe WerdnigHoffmann disease, with onset at birth or within the first few months of life and with death before the age of 2 years. In the second, more chronic, category the onset is usually later within the first year of life, and many patients survive, though severely disabled, for five to 10 years or even longer, though they are never able to walk. The third category, corresponding to the cases described by Kugelberg and Welander, comprises patients in whom muscular weakness becomes apparent later, within the first few years of life. Most of them are able to walk, though the rate of increase in their disability and of the progression of the disease is variable. While occasional families show $\mathrm{X}$-linked recessive or dominant inheritance, most cases of spinal muscular atrophy in childhood probably result from an autosomal recessive gene, though many continue to occur sporadically. The question whether the recessively inherited cases can indeed be classified into the three categories defined by $K$. Fried and A. E. H. Emery ${ }^{5}$ remains open, and an international collaborative study designed to answer it has recently been launched. 6

Diagnostic difficulties may arise in distinguishing between benign spinal muscular atrophy of the Kugelberg-Welander type on the one hand and Duchenne type muscular dystrophy on the other. These difficulties are heightened by the knowledge that substantial increases in the activity of creatine kinase in the serum, as well as electromyographic abnormalities sometimes suggesting a primary myopathy, may be observed in some of these cases, ${ }^{7}$ and even muscle biopsy does not invariably give conclusive findings, especially if histochemical techniaues of examining muscle sections are not available. So-called secondary myopathic change ${ }^{78}$ in muscle sections may obscure the underlying neurogenic nature of the condition, though histochemical type-grouping of muscle fibres may be a useful clue to the primary neurogenic character of the disease.

A. Moosa and V. Dubowitz ${ }^{9}$ have now drawn attention to two useful pieces of clinical evidence which may help in distinguishing cases of childhood spinal muscular atrophy. They note that there have been occasional previous reports $^{3}{ }^{10-13}$ of patients with spinal muscular atrophy who showed tremor of the limbs. And in the past three years they have seen 13 patients with spinal muscular atrophy of the benign childhood type all with coarse irregular tremor of the bands, particularly when the arms were held outstretched with the fingers splayed. In addition, they have noted that many patients with spinal muscular atrophy tend to walk flat-footed with eversion of the feet, while patients with typical Duchenne muscular dystrophy tend to walk on their toes, with evidence of an equinovarus type of foot deformity. Clearly therefore these signs should be sought when difficulty arises in distinguishing between benign spinal muscular atrophy and Duchenne muscular dystrophy in childhood. As Duchenne dystrophy is invariably a disease of males, diagnostic difficulty is less when the affected child is 
female, but in male patients these clinical clues could have some diagnostic value.

But ultimate diagnosis must depend on full investigation with electromyography, serum enzyme studies, and muscle biopsy. The distinction is important, because Duchenne muscular dystrophy is invariably a progressive and fatal disorder. In some patients with spinal muscular atrophy the disease may undergo temporary or even prolonged arrest, and often the prognosis is better than it is in cases of the Duchenne type. Furthermore, an accurate diagnosis is needed for genetic counselling, as the sisters of boys suffering from Duchenne dystrophy may possibly be carriers of the $\mathrm{X}$ linked gene, whereas unaffected sibs of a child with spinal muscular atrophy of autosomal recessive inheritance are unlikely to pass on the disease to their offspring unless they marry a blood relation.

1 Kugelberg, E., and Welander, L., Archives of Neurology and Psychiatry, $1956,75,500$.

2 Dubowitz, V., Brain, 1964, 87, 707

Gardner-Medwin, D., Hudgson, P., and Walton, J. N., fournal of the Neurological Sciences, 1967, 5, 12i.

4 Munsat, T. L., Woods, R., Fowler, W., and Pearson, C. M., Brain, 1969, 92, 9.

5 Fried, K., and Emery, A. E. H., Clinical Genetics, 1971, 2, 203.

6 World Federation of Neurology, Research Group on Neuromuscular Diseases, Fournal of the Neurological Sciences, 1973,18,493.

- Mastaglia, F. L., and Walton, J. N., Fournal of the Neurological Sciences, $1971,12,15$.

${ }^{8}$ Drachman, D. B., Murphy, S. R., Nigam, M. P., and Hills, J. R., Archives of Neurology, 1967, 16, 14 .

${ }^{9}$ Moosa, A., and Dubowitz, V., Archives of Disease in Childhood, 1973, 48 , 386.

${ }^{10}$ Brandt, S., Werdnig-Hoffmann's Infantile Progressive Muscular Atrophy.

Copenhagen, Munksgaard, 1950.
11 Byers, R. K., and Banker, B. Q., Archives of Neurology, 1961, 5, 140.

12 Spiro, A. J., Fogelson, M. H., and Goldberg, A. C., Developmental Medicine and Child Nourology, 1967, 9, 594.

13 Peters, H. A., Opitz, J. M., Goto, I., and Reese, H., Acta Neurologica Scandinavica, 1968, 44, 542.

\section{Does Crohn's Disease Predispose to Intestinal Cancer?}

It is a well-documented fact that long-standing ulcerative colitis predisposes to the development of carcinoma of the large intestine. ${ }^{1}$ This risk has to be taken into account when considering the practical management of patients suffering from colitis.

It is natural to ask whether the other common inflammatory condition of the intestinal tract, Crohn's disease, carries a similar potential for producing malignant tumours of the bowel. In a way it might be surprising if it did, for unlike ulcerative colitis, in which the inflammatory process is located predominantly in the mucosa, in Crohn's disease the maximal changes occur in the submucosa and deeper layers, though it is rare for the mucous membrane entirely to escape. But what counts is what actually happens in practice. There have been several attempts ${ }^{2-5}$ to assess the frequency of intestinal carcinoma in Crohn's disease and determine whether the two conditions are causally related or not. Most of these studies have reached rather equivocal conclusions, but recently S. G. Darke and his colleagues ${ }^{6}$ at the London Hospital have thrown fresh light on this debatable question.

Dealing first with carcinomas of the small bowel associated with Crohn's disease, Darke and his colleagues found that the average age at the time of diagnosis in 25 published cases was 46 years but that in a group of cases of small bowel carcinoma unassociated with Crohn's disease it was 61,7 a statistically significant difference. The distribution of the "Crohn's carcinomas" was different from that of spontaneously occurring carcinomas of the small bowel; the former occurred mainly in the lower ileum, the latter were more evenly located throughout the small intestine. ${ }^{8}$ The incidence of spontaneously occurring carcinoma of the small bowel has been estimated at 0.3 per 100,000 population per year. ${ }^{10}$ The prevalence of Crohn's disease at all sites in the intestinal tract has been put at 9 per 100,000.11 The chances of the two conditions occurring together is thus no more than 1 in a thousand million. But in several large series of published cases of Crohn's disease of the small bowel the incidence of carcinoma averaged $0.3 \%$.

As to "Crohn's carcinomas" of the large bowel, Darke and his colleagues found that there was no significant difference between the average age at diagnosis of these growths and that of spontaneously occurring colo-rectal carcinomas. ${ }^{12}$ However, the distribution of these two forms of growth was dissimilar in that the Crohn's carcinomas were commoner in the proximal colon, the ordinary colo-rectal cancers in the distal colon and rectum. ${ }^{13}$ As regards overall incidence, Darke and colleagues calculated from several sources ${ }^{14} 15$ that the incidence of spontaneously occurring carcinoma of the large bowel is roughly 60 per 100,000 population. The prevalence of Crohn's disease of the colon and rectum is probably about 6 per $100,000.11$ The chances of a coincidental association of carcinoma and Crohn's disease of the large intestine is thus about 1 in 10 million. But the actual incidence of carcinoma in the colon and rectum associated with Crohn's disease averages $1.8 \%$ in published series. ${ }^{6}$

As a consequence of these observations Darke and his colleagues ${ }^{6}$ consider that there is a small but significant risk of carcinoma developing, both in the small and in the large intestine, in Crohn's disease.

${ }^{1}$ Goligher, J. C., de Dombal, F. T., Watts, J. M., and Watkinson, G. Ulcerative Colitis. London, Baillere, Tindall and Cassel, 1968.

2 Shiel, F. O'M., Clarke, C. G., and Goligher, J. C., British fournal of Surgery, 1968, 55, 53 .

3 Perrett, A. D., Truelove, S. C., and Massarella, G. R., British Medical Fournal, 1968, 2, 466 .

4 Jones, J. H., Gut, 1969, 10, 651.

5 Wyatt, A. P., Gut, 1969, 10, 924

Darke, S. G., Parks, A. G., Grogono, J. L., and Pollock, D. J., British Fournal of Surgery, 1973, 60, 169

Brookes, V. S., Waterhouse, J. A. H., and Powell, D. J., British fournal of Surgery, 1968, 55, 405.

${ }^{8}$ Rochlin, D. B., and Longmire, W. P., Surgery, 1961, 50, 586.

Ackerman, L. V., and Del Regato, J. A., Cancer Diagnosis, Treatment and Prognosis, 3rd edn., p. 626. St. Louis, Mosby, 1962.

${ }^{10}$ Haffner, J. F. W., and Semb, L. S., Acta Chirurgica Scandinavica, 1969, $135,543$.

${ }^{11}$ Evans, J. G., and Acheson, E. D., Gut, 1965, 6, 311

12 Goligher, J. C., British Medical fournal, 1941, 2, 393.

13 Smiddy, F. G., and Goligher, J. C., British Medical fournal, 1957, 1, 793.

Registrar General, Statistical Review of England and Wales for the Year 1969, Part 1, Tables, Medical. London, H.M.S.O., 1971.

15 Cutler, S. J., and Lourie, W. I., National Cancer Institute Monograph No. 15, p. 281 . U.S. Department of Health, Education, and Welfare, 1964.

\section{Starting Young}

Though the dangers of cigarette smoking ane plain enough to medical men they appear unconvincing to a large number of lay people. But if the young are ever to be deterred from starting the habit at least one necessity is for their elders to set a better example than many do at present. Children would not be human if they did not imitate adults. That plenty do so to become smokers even at the age of 10 is apparent from a recent report. 